\begin{tabular}{ccc}
\hline International Journal of Engineering \& Technology, $7(3.21)(2018) 431-436$ \\
SPC & Website $: \frac{w w . s c i e n c e p u b c o . c o m / i n d e x . p h p / I J E T}{2}$ \\
Research paper & Technology \\
\hline
\end{tabular}

\title{
Relationships between Attitude Towards Behaviour, Subjective Norm, Self-Efficacy and Entrepreneurial Intention Among the Technical Secondary Students in Malaysia
}

\author{
Saraih, U. N. ${ }^{1}{ }^{*}$, Amlus, M. H. ${ }^{2}$, Irza Hanie Abu Samah ${ }^{3}$, Abdul Mutalib, S. ${ }^{4}$, Ain Zuraini Zin Aris ${ }^{5}$, Sharmini, A. ${ }^{6}$ \\ ${ }^{1,2,3,5}$ School of Business Innovation \& Technopreneurship, Universiti Malaysia Perlis, 01000 Kangar Perlis, Malaysia. \\ ${ }^{4}$ School of Human Development \& Technocommunication, Universiti Malaysia Perlis, 01000 Kangar Perlis, Malaysia. \\ ${ }^{6}$ Centre of International Languages, Universiti Malaysia Perlis, 01000 Kangar Perlis, Malaysia. \\ *Corresponding author E-mail: ummi@ unimap.edu.my
}

\begin{abstract}
The present study investigated the relationships between the three factors of Theory of Planned Behavior (TPB) and entrepreneurial intention among students from the Technical Secondary School in Malaysia. This study utilized the survey (questionnaire) method. A total of 163 respondents which consisted of the Year 4 students from one of the Technical Secondary School in Northern Region of Malaysia were selected to participate in this study. The findings presented that students in this institution have a high level of entrepreneurial intention (mean=3.89). Also, results presented that subjective norm is the only factor that significantly related to entrepreneurial intention $(\beta=.331, \mathrm{p}=.000)$. Meanwhile, other factors such as attitude towards behavior $(\beta=.064, \mathrm{p}=.474)$ and self-efficacy $(\beta=.070, \mathrm{p}=.438)$ are not significantly related to entrepreneurial intention. Thus, it is found that only one factor of TPB which is subjective norm has a significant relationship with entrepreneurial intention among students in this Technical Secondary School. This study contributed some fruitful knowledge which can be suggested to all Technical Secondary Schools to improve the level of students' entrepreneurial intention, particularly in the Malaysian context. Implications of the results are discussed; and future research direction are briefly provided.
\end{abstract}

Keywords: Entrepreneurial intention; attitude towards behaviour; subjective norm; self-efficacy

\section{Introduction}

In the local context, the number of entrepreneurs and the amount of entrepreneurial activity is still in a less favorable stage when viewed with the numbers of entrepreneurs in the outside world. Several factors such as financial support, issues in government procedure, limited training and education in the tertiary education level are seen as the main causes that led to the reasons of why most individuals reluctant to set up their own business (1). Therefore, in order to be ranked as one of the developed nations by 2020 , the Malaysian Ministry strives to strategize some specific plans to polish the entrepreneurial skills among students in the tertiary education level. At the same time, it is expected that entrepreneurship education can support the growth of entrepreneurial activities among the youths in Malaysian.

Recognizing the importance of entrepreneurship education in promoting entrepreneurship development and the economy, MoHE or the Ministry of Higher Education Malaysia forces an initiative by placing entrepreneurship in the curricular structure in most of the programs offered in the public universities. Hence, the efforts of this initiative can lead to the less unemployed graduates and can increase the business opportunities, which in turn can create an impact towards placing Malaysia in the status of the developed nation by Year 2020 (2).

To this point, MOHE has launched the National Education Blueprint (Higher Education). As documented in the blueprint, ten shifts have been targeted to be achieved by MoHE in Year 2025.
Entrepreneurial element has been focused among the most important one, and has been highlighted in the first shift. As stated in the blueprint, MoHE aimed to produce holistic students with the entrepreneurial minds. Mazdan (3) said that self-employment as an entrepreneur is an alternative for graduates to start their careers besides to be employed in the organization due to the volatile limited job market and high rate of retrenchment.

However, the most crucial matter to the nation is to trigger some elements on entrepreneurial minds among students not only when they are in the tertiary education level, but it should be nurtured while they are still in the secondary education level. Supported by a research of Mansor et al.s (4) who claimed that the element of entrepreneurial should be focused among students in the secondary education in order to develop those potential students and lead them to achieve their career of self-employment. Given that, secondary schools are the best platform to create the intention among students to become the future entrepreneurs. Moreover, students from the secondary schools are those who are expected to continue their entrepreneurial study in the tertiary education level. Thus, initial efforts towards having the entrepreneurial minds can be cultivated among students in the secondary education level(5).

The Malaysian Government takes a step further to advise TVET students to enter the entrepreneurial world by formulating entrepreneurship program in TVET academic structure. As stated by (6), the estimation of 1000 TVET institutions have been operated in Malaysia. For instance, Polytechnic and Community College are the examples of TVET institutions which have been monitored by Ministry of Higher Education (MoHE). Meanwhile, some other TVET institutions (eg. IKM, Giat-MARA, JMTI, ADTEC) have 
been monitored by Ministry of Regional and Rural Development (MoRRD), Ministry of Youth and Sports (MoYS) and Ministry of Human Resources (MoHR). All of these TVET institutions are expected to assist the government in strengthening entrepreneurial skills among students in Malaysia.

Given the important of TVET institutions to create an impact on entrepreneurship to the nation, several local studies on entrepreneurship among students in TVET institutions have been reported (5). However, limited knowledge has known on entrepreneurship among the younger students especially from the Technical Vocational Schools in Malaysia. Therefore, the researchers attempt to focus on several factors which may create influences on entrepreneurial intention among these secondary group of students in Malaysia. Referring to (7) theory of TPB, this study aims to reveal some predictors of students' entrepreneurial intention in the technical school in Malaysia.

\section{Literature Review}

The aim of this section is to provide the related literature based on past empirical studies. Specifically, in the first place, this section reviews the importance of entrepreneurial intention. In the second stage, literature review the concept of TPB. Next, the concept of attitude towards behavior, subjective norm and self-efficacy are discussed. At the same point, related empirical studies on the relationships between the selected predictors and entrepreneurial intention are explained in order to develop the research hypotheses.

\subsection{Attitude towards Behaviour, Subjective Norm and Self-Efficacy}

Ajzen developed the Theory of Planned Behavior (TPB) as it rooted by the Theory of Reasoned Action (TRA). This theory uses attitudes, subjective norm and PBC (perceived behavioural control) to forecast intention with a like high accuracy. TPB can be categorized into three concepts which able to predict the behavioural intention included of attitude towards the behaviour, subjective norm and perceived behavioural control. Behavioural intention is referred to entrepreneurial intention in this present study. TPB suggests that important beliefs are the determinants of attitude towards behaviour, subjective norm and perceived behavioural control. In this model, behavioural beliefs trigger the individuals' attitude towards behaviour, normative beliefs formulate the individuals' subjective norm, and control beliefs lead the individuals' perceived behavioural control.

According to Ajzen (7), attitude toward behaviour refers to the extent of individual assessment toward his/her own performance of that behaviour. In this study, attitude towards behaviour refers to students' assessment towards their own performance of entrepreneurial behaviour. Subjective norm measures on how individuals perceive the close person in their surrounding think they could execute the behaviour. The perceived opinions of these close person encourage them to decide whether they will execute the behaviour or not. In this study, subjective norm refers to students' perceived opinions about other key people in their lives (eg. parents, teachers, friends, etc.) think about themselves whether they will perform the behaviour (entrepreneurial behaviour) or not Perceived behavioural control is the perceptions on individuals whether they can execute the targeted behaviour and how convenient they perceive that they can realize it. In this study, selfefficacy is used to refer the perception of students whether they can execute that targeted behaviour (entrepreneurial behaviour) or not. This is because perceived behavioural control means the perceptions of individuals about their capability to execute a targeted behaviour. Thus, some items of perceived behavioural control reflect on person's perception of self-efficacy on realizing a targeted behaviour (8). Thus, TPB implies the concepts of selfefficacy or perceived behavioural control in a wider scope to ex- plain the relationships among perceptions, intentions, and behaviour.

\subsection{Entrepreneurial Intention}

Past researchers (9) defined entrepreneurial intention as a state of mind that people wish to create a new firm or a new value driver inside existing organizations. Specifically, \{Liñán, 2004 \#24\} defined entrepreneurial intention as the efforts of a person to carry out entrepreneurial behaviour. Intentions are triggered by attitudes, and attitudes are caused by internal factor, external factors or both. Based on the existing literature $(7,10,11)$ different aspects such as personality, education program, and environmental factor (family background) and have been found as the predictors of entrepreneurial intention.

Encouraging entrepreneurship is particularly important to face challenges related to alarmingly high youth unemployment rates in most of the European Union Member States. Entrepreneurship and self-employment offer pathways for young people to emerge from unemployment. To achieve this, there is a need to encourage young people, to instill a spirit of entrepreneurship from early on in life; and to help them in the transition from school to adulthood (12).

As stated by Abbas (13), the elements in entrepreneurship program (eg. objectives, contents, teaching methods) are salient to students because it leads to the positive output for the entrepreneurial intention. Other study Hussain (10) presented that entrepreneurial education is significantly related to students' entrepreneurial intention among Pakistani. The findings indicated that entrepreneurship education might create a difference on students' attitude and mind set after they accomplished the entrepreneurial program. Also, past research revealed a significant relationship between environmental factors (eg. family decisions, family backgrounds) and entrepreneurial intention. For example, (11) presented that people who originated from entrepreneur families background have more intention to become the entrepreneurs in Malaysia.

However, for the purpose of this study the researchers have referred to TPB as the theory to explain the relationships among students' attitude, subjective norm, self-efficacy and their entrepreneurial intention. Although TPB has been investigated as the factor to determine entrepreneurial intentions in the previous entrepreneurship studies (14), lack is known regarding the impact of attitude, subjective norm and self-efficacy on students from technical schools especially in the local context. Therefore, this study attempts to reveal the potential influence of three TPB factors on students' entrepreneurial intention in the Malaysian technical secondary school.

\subsection{Predictors of Entrepreneurial Intention}

There are differences of concepts in attitude, subjective norm and self-efficacy which enable these factors to determine the targeted behaviour of individuals based on the existing empirical works. Individuals' attitudes can trigger individuals' intention which can reflect into some kind of individuals' behaviour. Thus, individuals' intention towards entrepreneurship can be claimed as the main factor which can lead them to have the entrepreneurial behaviour. This was supported by (15) who presented that intention has a significant influence to predict entrepreneurial behaviour.

The first factor of TPB in this study is attitude towards behaviour. Generally, the more individuals assess themselves to become the entrepreneurs, the stronger they will intent to execute their behavioural to become the entrepreneurs. Several evidences have been found to examine the relationship between attitude and entrepreneurial intention. For instance, Rudhumbu et al. (16) found that students who have a positive attitude towards entrepreneurial education would like to choose entrepreneurship as their future career. Other authors (17) also revealed a significant association between personal attitude and entrepreneurial intention. 
Subjective norm is the second factor of TPB in this study. It refers to individuals' perceived opinions of key persons who encourage them to execute or not to execute the entrepreneurial behaviour. These key persons might be the close individuals to the students such as their families, teachers, friends and any possible role models. According to Krithika \& Venkatachalam,(18), the more supportive the subjective norm, the higher intention to be performed. If the targeted behaviour is more attractive to the individuals (students), the intention of the individuals (students) will be higher. Therefore, the perceived opinion of key persons whether to encourage or not to encourage them in entrepreneurship as their future careers, is one of the reasons which called the subjective norm. For example, (18) found that subjective norm was a salient factor which can create impact on entrepreneurial intention among the business students in Bangalore.

The third factor of TPB in this study is self-efficacy. According to Stankiewicz \& Wasilczuk, (19), self-efficacy is a concept of individuals' beliefs about their own capabilities to realize a targeted performance. With regards to this point, (19) investigated the effect of self-efficacy on entrepreneurial intention among young polish people in Poland. They confirmed that people who perceived themselves as self-efficacy reported to open own firm in the future more often than others.

Given the above literature review, this research aims to reveal the relationships between the predictors (eg. attitude towards behaviour, subjective norm and self-efficacy) and students' entrepreneurial intention from one Technical School in the Northern Region of Malaysia. Below are the developed hypotheses for this study:

$\mathrm{H}_{1}$ : Attitude towards behaviour and students' entrepreneurial intention is significantly related.

$\mathrm{H}_{2}$ : Subjective norm and students' entrepreneurial intention is significantly related.

$\mathrm{H}_{3 \text { : }}$ Self-efficacy and students' entrepreneurial intention is significantly related.

\section{Methodology}

This study has utilized the quantitative method (eg. questionnaire) The population of this study included all year 4 students in all files in this school. Therefore, the survey sets have been randomly distributed for approximately 200 respondents. The instruments used for this study have been adapted from the previous measurements. As for the entrepreneurial intention, 4 items of (20) scale has been adapted. With regards to the first independent variable, 4 items of attitude towards behaviour has been adapted from (20). Meanwhile, 3 items of subjective norm from(21) has been utilized. Last but not least, the 8 items of self-efficacy from (22) has been used. Out of 200 distributed questionnaire, 163 returned questionnaire sets have been used for analysis by using SPSS software (version 22). Separate multiple regression has been run to test the predictive power of independent variables on dependent variable accordingly to the developed hypotheses.

\section{Findings Analysis}

Findings analysis has been discussed based on the descriptive and statistical analyses. The descriptive analysis discussed the profile of the respondents. Meanwhile the statistical analyses discussed the results of the used SPSS test (reliability, correlation analysis, regression analysis).

\subsection{Profile of the Respondents}

Table 4.1 presented the demographic data of respondents included their gender, race and their field of studies. Based on the profile of respondents, it is noted that more than half of the respondents were males which contributed of $52.1 \%$ (85 participants). Hence, the other $47.9 \%$ or 78 out of 163 participants of this present study were female respondents.

More than three quarter of the participants which presented about $97.5 \%$ (159) were Malays. Only a small percentage of $2.5 \%$ (4) were Chinese. None of the respondents ticked for the categories of Indians or others as their race in this study.

With regards to the twelve fields of study in this schools, the respondents came from the various types of filed. The majority of the respondents came from Manufacturing Technology field which contributed a percentage of $13.5 \%$. This figures were followed by Cosmetology (12.9\%), Fashion (12.3\%), Business Management $(11.7 \%)$, Cooling and Air Conditioning Technology (8.6\%), Electronic Technology (8.0\%), Culinary Art (7.4 \%), Welding Technology (6.7\%), System Computer (6.1\%), Automotive Technology (4.9\%), and Machinery Industry Technology $(4.9 \%)$. The small percentage of the respondents which contributed of $3.7 \%$ came from students from the Electric Technology.

Table 4.1: Demographics Data

\begin{tabular}{|l|l|l|}
\hline Demographics & Frequency & Percentage (\%) \\
\hline Gender & & \\
\hline Male & 85 & 57.1 \\
\hline Female & 78 & 47.9 \\
\hline Race & & \\
\hline Malays & 159 & 97.5 \\
\hline Chinese & 4 & 2.5 \\
\hline Indians & 0 & 0.0 \\
\hline Others & 0 & 0.0 \\
\hline Field of Studies & & \\
\hline Electric Technology & 6 & 3.7 \\
\hline Electronic Technology & 13 & 8.0 \\
\hline Automotive Technology & 8 & 4.9 \\
\hline Manufacturing Technology & 22 & 13.5 \\
\hline Machinery Industry Technology & 7 & 4.3 \\
\hline Welding Technology & 11 & 6.7 \\
\hline $\begin{array}{l}\text { Cooling and Air Conditioning } \\
\text { Technology }\end{array}$ & 14 & 8.6 \\
\hline System Computer & 10 & 6.1 \\
\hline Culinary Arts & & 7.4 \\
\hline Cosmetology & & 12.9 \\
\hline Fashion & 19 & 12.3 \\
\hline Business Management & 11.7 \\
\hline
\end{tabular}

\subsection{Reliability Analysis}

As presented in Table 4.2, the Cronbach Alpha values ranged from 0.65 for self-efficacy, 0.68 for subjective norm, 0.69 for attitude towards behaviour and 0.72 for entrepreneurial intention. Thus, the reliability values for all variables are accepted in this present study (23).

Table 4.2: Reliability Analysis

\begin{tabular}{|l|l|l|l|}
\hline Variables & $\mathbf{N}$ & $\begin{array}{l}\text { Cronbach's } \\
\text { Alpha }\end{array}$ & Remark \\
\hline $\begin{array}{l}\text { Entrepreneurial In- } \\
\text { tention }\end{array}$ & 163 & 0.723 & Acceptable \\
\hline $\begin{array}{l}\text { Attitude towards } \\
\text { Behaviour }\end{array}$ & 163 & 0.688 & Acceptable \\
\hline Subjective Norm & 163 & 0.681 & Acceptable \\
\hline Self-Efficacy & 163 & 0.648 & Acceptable \\
\hline
\end{tabular}

\subsection{Mean, Standard Deviation, Minimum and Maxi- mum Results}

Table 4.3 indicated the mean, $\mathrm{SD}$, min and max results for variables in the present study. The means were high for all variables. Results presented that means were 3.72 for self-efficacy, 3.78 for subjective norm, 3.84 for attitude towards behaviour and 3.89 for entrepreneurial intention. Therefore, it showed that all participants in this present study have a high level of entrepreneurial intention, attitude towards entrepreneurial intention, subjective norm and self-efficacy. 
The minimum of 1.33 for subjective norm indicated that some of the respondents perceived other key people in their lives (eg. parents, teachers, friends, etc.) believed they are not performed the behaviour that related to entrepreneurial. This could be due to the failure of the parents or teachers in some aspects towards increasing the subjective norm among the students. However, the minimum values of 1.75 for self-efficacy showed that some of the students were in the middle range and perceived they can perform the behaviour that specifically referred to entrepreneurial. Thus, the way on how parents and teachers may build the interest among them to become entrepreneurs in future is salient to be nurtured The minimum value of 2.00 for attitude towards behaviour (entrepreneurial) indicated that some of the respondents already have almost half of the positive evaluation towards their performance of entrepreneurial behaviour within themselves.

In contrast, the maximum values of 5.00 for entrepreneurial intention indicated that some of the respondents highly perceived that they placed full efforts to carry out entrepreneurial behaviour Similarly, the maximum score of 5.00 were reported for all the predictors. Maximum score for attitude towards behaviour showed that some respondents perceived that they were fully performed their attitude towards entrepreneur. Maximum score of selfefficacy presented that some of the students believed that their capabilities to produce entrepreneur's performance was at the full level. Maximum score of subjective norm implied that some of the respondents perceived other key people in their lives (eg. parents, teachers, friends, etc.) believed they are fully performed the behaviour that related to entrepreneurial.

By examining the values of SD, variability can be assed as SD measured the amount of variability in the distribution of a variable. As presented in table 4.2, the SD for entrepreneurial intention and attitude towards entrepreneurial intention were at 0.60 . As for the variables of self-efficacy and subjective norm the report presented values of 0.72 and 0.67 each. The data showed that majority of participants were close to the mean. SD for self-efficacy is reported to has the highest value of 0.72 .

Table 4.3: Mean, Standard Deviation, Minimum and Maximum Values

\begin{tabular}{|l|l|l|l|l|l|}
\hline Variables & $\mathbf{N}$ & Mean & SD & Minimum & Maximum \\
\hline $\begin{array}{l}\text { Entrepreneurial } \\
\text { Intention }\end{array}$ & 163 & 3.8896 & 0.6023 & 1.75 & 5.00 \\
\hline $\begin{array}{l}\text { Attitude to- } \\
\text { wards Behav- } \\
\text { iour }\end{array}$ & 163 & 3.8374 & 0.6026 & 2.00 & 5.00 \\
\hline $\begin{array}{l}\text { Subjective } \\
\text { Norm }\end{array}$ & 163 & 3.7270 & 0.6688 & 1.33 & 5.00 \\
\hline Self-Efficacy & 163 & 3.7832 & 0.7234 & 1.75 & 5.00 \\
\hline
\end{tabular}

\subsection{Correlation Analysis}

Correlation analysis is used to measure the relationships between all predictors (attitude towards behaviour, subjective norm, and self-efficacy) and the criterion (entrepreneurial intention). The detail results for inter-correlation between variables this study were given in Table 4.4. As presented in Table 4.4 correlations between attitudes towards behaviour, subjective norm and selfefficacy showed bivariate relationships with entrepreneurial intention in this study. The first correlation between attitudes towards behaviour and entrepreneurial intention is significantly correlated $(\mathrm{r}=.26, \mathrm{p}<.01)$. Second, subjective norm and entrepreneurial intention is also significantly correlated $(r=.27, \mathrm{p}<.01)$. Also, the third predictor namely self-efficacy is significantly correlated with entrepreneurial intention $(\mathrm{r}=.39, \mathrm{p}<.01)$.

Table 4.4: Correlation Analyses between Attitude towards Behaviour Self-Efficacy, Subjective Norm and Entrepreneurial Intention

\begin{tabular}{|l|l|l|}
\hline \multirow{3}{*}{ Variables } & \multicolumn{2}{|c|}{ Entrepreneurial Intention } \\
\hline \multirow{2}{*}{ Sttitude towards Behaviour } & Person Correlation & $0.264^{* *}$ \\
\cline { 2 - 3 } & Sig. (2-tailed) & 0.00 \\
\cline { 2 - 3 } & $\mathrm{N}$ & 163 \\
\hline Subjective Norm & Person Correlation & $0.271^{* *}$ \\
\hline
\end{tabular}

\begin{tabular}{|l|l|l|}
\hline \multirow{4}{*}{ Self-Efficacy } & Sig. (2-tailed) & 0.00 \\
\cline { 2 - 3 } & $\mathrm{N}$ & 1.63 \\
\hline & Person Correlation & $0.398^{* *}$ \\
\cline { 2 - 3 } & Sig. (2-tailed) & 0.00 \\
\cline { 2 - 3 } & $\mathrm{N}$ & 1.63 \\
\hline
\end{tabular}

**Correlation is significant at the 0.01 level (2-tailed).

\subsection{Regression Analysis}

Regression analysis is presented in Table 4.5. This analysis is used to measure which variables among the attitude towards behaviour, subjective norm and self-efficacy have created the most significant influence on the level of entrepreneurial intention among students in this study. As presented in Table 4.5, it is noted that $17 \%$ $\left(\mathrm{R}^{2}=.17, \mathrm{~F}=10.69\right)$ of the variance in entrepreneurial intention is explained by attitude towards behaviour, subjective norm and selfefficacy.

Based on the results, only one dimension of TPB which is subjective norm is significantly related to entrepreneurial intention $(\beta=.331, p=.000)$. However, it is found that attitude towards behaviour $(\beta=.064, \mathrm{p}=.474)$ and self-efficacy $(\beta=.070, \mathrm{p}=.438)$ are not significantly related to students' entrepreneurial intention.

Table 4.5: Regression Analyses between Attitudes towards Behaviour, Subjective Norm, Self-Efficacy and Entrepreneurial Intention

\begin{tabular}{|l|l|l|l|}
\hline Variables & \multicolumn{3}{|c|}{ Entrepreneurial Intention } \\
\hline Attitude towards Behaviour & Beta & t-Ratio & Sig \\
\hline Subjective Norm & 0.064 & 0.718 & 0.474 \\
\hline Self-Efficacy & 0.331 & 3.766 & 0.000 \\
\hline $\mathrm{R}^{2} 0.168$ & 0.070 & 0.778 & 0.438 \\
\hline $\mathrm{F}=10.692$ & & & \\
\hline \multirow{4}{|l|}{ *Correlation is significant at the 0.05 level (2-tailed). }
\end{tabular}

\section{Conclusions}

Multiple discussions with fundamental analysis have been done in this research to study about the connection in between entrepreneurial intention and independent variables namely attitude towards behaviour, subjective norm and self-efficacy. The debates on each variable are continuously arises among practitioners and there might be an ongoing research will be done to check out the impact of certain variables towards entrepreneurial intention. Entrepreneur can be one type of the career which is involved many challenging times compare to other common careers out there. This study gives some insight on what drive these students to decide on their after-study path in part of entrepreneurship elements. As nowadays is a live for the better competitor, the intention for entrepreneurship is a good phenomenon that should be encouraged among youth to cope with the hectic lifestyle and needs today. Entrepreneurship can be a savior for reducing an unemployment rate in a country as it is not only impact to one individual but there will be opportunities to create new jobs.

This research found that only subjective norm is significantly related to entrepreneurial intention. The results of other two independent variables which are attitude towards behaviour and selfefficacy are oppositely. The results found is supported by a study from (18) found similar outcome among 100 business students in Bangalore. Another study that supported the results of this research is the one from (24) that did a study among 413 students from various faculties and schools at Public University in Malaysia. They found significance relationship between one of the motivation factor which is subjective norm to entrepreneurial intention. Thus, it can be said that people surrounding are interrelated in influencing these individuals to intent in furthering on entrepreneurial line. They behave in what they want others look at them. Parent's career hood and friend's encouragement affect their mindset to opt the best line to join in the work context.

The results of significant relationship between subjective norm to entrepreneurial intention may lead by the influences on several 
factors such as awareness of an entrepreneurial career, supporting networks and role models (25). It can be said that family background and surrounding play some important role as these variables expose individuals to the entrepreneurship elements at an early age (25). Encouragement to the intention of entrepreneurship might be facilitated by connection with present entrepreneurs, bringing together students with entrepreneurial aspirations, and talk by alumni who had become successful entrepreneurs, participation with the business activities during internship or getting in touch with academicians with an entrepreneurial spirit. Oppositely, (26) found insignificant relationship between subjective norm and entrepreneurial intention among 186 students of Greek University. Additionally, the results of (9) failed to relate subjective norm and entrepreneurial intention among Chinese students in Shanghai. Similarly, the outcomes of (27)) also found that subjective norm does not associate to entrepreneurial intention among students. These insignificant relationships could be affected by dominances of environmental factors among students to join as an entrepreneur sooner.

However, two independent variables which refer to attitude towards behaviour and self-efficacy did not related to entrepreneurship intention. The findings were supported by(28) who found insignificant relationship between attitude towards behaviour and entrepreneurship intention among MBA students. Traditionally, individuals may fall onto several categories to be as followers or leaders, willing to comply in other's direction or prefer to develop their direction. Align with this statement, previous researchers (29) proposed that the entrepreneurship intention began with the decision-making style individual has and empowerment within the person to follow the flow or challenge the work-circle. People who tend to enter self-employment area are generally tuned to the span of control that they are comfort with. Nevertheless, in real work-environment, the span of control might be limited due to many factors such as investors, creditors, labor unions and customers researchers (29). Other researchers (30) mentioned that individual's attitude towards entrepreneurship are rely on external factors such as education and previous experience.

In the context of entrepreneurship, the business owners who tend to have lower self-efficacy may completely trying to avoid certain challenging task because of the lack of belief in self-capability to fix or face the challenges occur(31). Several studies reported that no differences between gender feedback in terms of selfefficacy(25). However, the limitations of the generalization of such point of views might vary across countries as influences by many culture factors. For example, (32) suggested that reinforcements on motivating factors can be done in order to overcome low entrepreneurial intention among students. Motivating factors such as achievement, responsibilities and advancement should be given to the individuals to improve their passion in entrepreneurship. Practical training for students in entrepreneurship education line or such need to be organized carefully by inserting training elements for graduate entrepreneurship regularly so that they can get the benefit of linkages of learning from peers (32). Not only that, mentorship approach can also be instituted by government agencies to assist students to participate in entrepreneurship intervention at tertiary institutions. Thus, the mentorship approach may be the suitable criteria to be applied in the Technical Secondary School in Malaysia. This is because the successful entrepreneurs can be the best mentor to brush the willingness among students in developing oneself desire to be good entrepreneurs in the future. Hence, the successful entrepreneurs may inspire them by giving some knowledge sharing about success and failures moments for living in an entrepreneurship circle.

With that, it can be said that factors surrounding a person play a major impact in influencing students to pursue for entrepreneurship continuously. In fact that there have some space to fix the phenomenon for a better entrepreneur-minded nation. Education institutions also play a major role to ensure a quality curricular development to help students not only just understanding the concepts but at the same time applying those for keeping up a good skills in every context for self-development in work-life timeline. This research is hoped to give some knowledge on current outcomes gaining so that it can give some ideas on tackling the situation mentioned. Overall, entrepreneurship intention among students in this study is relatively high with mean reported at 3.89. Thus, the appropriate actions need to be improved to maintain the high level of entrepreneurial intention among students in this technical secondary institution. Although this study investigated the influences of TPB variables on student's entrepreneurial intention, it can be proposed that other variables (eg. motivation, practical training, mentorship, etc.) might be included in the future entrepreneurial intention studies.

\section{References}

[1] Ahmad SZ, Xavier SR. Entrepreneurial environments and growth : Evidence from Malaysia GEM data. Journal of Chinese Entrepreneurship. 2012;4(1):50-69.

[2] Hardy Loh R, M. A. Bahari AK, Zanariah ZA, Junainah J, Laila MK, N. Faizah ML, et al. Entrepreneurship education in Malaysia: A critikal review. Journal of Technology Management and Business. 2015;02(02):1-11.

[3] Mazdan AA. Involvement of Graduate in the Field of Entrepreneurship in Kuala Lumpur, Malaysia. International Journal of Liberal Arts and Social Science. 2015;3(9):8-.

[4] Mansor N, Shaikh Ali SH, Abdul Ghani NA. Entrepreneurial Intention: Does Malaysian Secondary School Provide the Platform? Kuwait Chapter of Arabian Journal of Business and Management Review. 2011;1(3):19-35.

[5] Ibrahim WNA, Bakar AR, Asimiran S, Mohamed S, Zakaria NS. Impact of Entrepreneurship Education on the Entrepreneurial Intentions of Students in Technical and Vocational Education and Training Institutions ( TVET ) In Malaysia. International Education Studies. 2015;8(12):141-56.

[6] Leong PC, editor Key Reforms in Revitalising Technical and Vocational Education and Training (TVET) in Malaysia2011 2011.

[7] Ajzen I. The Theory of Planned Behavior. Organizational behavior and human decision processes. 1991;50:179-211.

[8] Ajzen I. Constructing a TPB questionnaire : Conceptual and methodological considerations. 2006. p. 1-14.

[9] Wu S, Wu L. The impact of higher education on entrepreneurial intentions of university students in China. Journal of Small Business and Enterprise Development. 2008;15(4):752-74.

[10] Hussain A. Impact of Entrepreneurial Education on Entrepreneurial Intentions of Pakistani Students. Journal of Entrepreneurship and Business Innovation. 2015;2(1):43-53.

[11] Mazlina M, Selvaraju M. Personal attributes, family influences, entrepreneurship education and entrepreneurship inclination among university students. Kajian Malaysia. 2015;33(1):155-72.

[12] European C. Focus on : Young people and entrepreneurship. 2013

[13] Abbas LN. Engineering Students : What factors effects their entrepreneurial intention? IOSR Journal Of Humanities And Social Science. 2013;15(2):35-40.

[14] Karimi S, Biemans HJA, Lans T, Mulder M, Chizari M, editors. The Role of Entrepreneurship Education in Developing Students Entrepreneurial Intentions2012; The Netherlands: The 10th Wageningen International Conference on Chain and Network Science.

[15] Krueger NF, Reilly MD, Carsrud AL. Competing Models of Entrepreneurial Intention. Journal of Business Venturing. 2000;15:411-32.

[16] Rudhumbu N, Svotwa D, Munyanyiwa T, Mutsau M. Attitudes of students towards entrepreneurship education at two selected higher education institutions in Botswana: A critical analysis and reflection. Academic Journal of Interdisciplinary Studies. 2016;5(2):83-94.

[17] Ferreira JJ, Raposo ML, Rodrigues RG, Dinis A, Paço AD. A model of entrepreneurial intention: An application of the psychological and behavioral approaches. Journal of Small Business and Enterprise Development. 2012;19(3):424-40.

[18] Krithika J, Venkatachalam B. A Study on Impact Of Subjective Norms On Entrepreneurial Intention Among The Business Students In Bangalore. IOSR Journal of Business and Management. 2014;16(5):48-50.

[19] Stankiewicz K, Wasilczuk J. Attitude and self-esteem versus entrepreneurial intentions among young in Poland. 2012. 
[20] Liñán F. Intention-Based Models of Entrepreneurship Education. Piccolla Impresa/Small Business. 2004;3(1):11-35.

[21] Kolvereid L. Organisational employment versus self-employment: Reasons for career choice intentions. Entrepreneurship Theory and Practice. 1996;20(3):23-31.

[22] Chen G, Gully SM, Eden D. Validation of a New General SelfEfficacy Scale Organizational Research Methods. Organizational Research Methods. 2001;4:62-83.

[23] Bryman A, Cramer D. Quantitative Data Analysis With SPSS 12 and 13. 1st ed. New York: Routledge, Francis \& Taylor; 2005. 236p.

[24] Kim-soon N, Ahmad AR, Ibrahim NN. Theory of Planned Behavior : Undergraduates , Entrepreneurial Motivation and Entrepreneurship Career Intention at a Public. Journal of Entrepreneurship: Research \& Practice. 2016;2016:1-14.

[25] Dato-on MC, Mueller SL. Gender-Role orientation as determinant of entrepreneurial self-efficacy. Journal of Developmental Entrepreneurship. 2008;13(1):1-35

[26] Tsordia C, Papadimitriou D. The Role of Theory of Planned Behavior on Entrepreneurial Intention of Greek Business Students. International Journal of Synergy and Research. 2015;4(1):23-37.

[27] Solesvik MZ, Westhead P, Kolvereid L, Matlay H. Studen intentions to become self-employed: The Ukrainian context. Journal of Small Business and Enterprise Development. 2012;19(3):441-60.

[28] Douglas E, Shepherd D. Self-employment as a Career Choice: Attitudes, entrepreneurial intentions and utility maximization. Entrepreneurial Theory and Practice. 2002;26(3):81-90.

[29] Fitzsimmons J, Evan J D, editors. Entrepreneurial Attitudes and Entrepreneurial Intentions: A Cross-Cultural Study of Potential Entrepreneurs in India, China, Thailand and Australia2005; Wellesley.

[30] Basu A, Virick M. Assessing Entrepreneurial Intentions Amongs Students : A Comparative Study Peer-Reviewed Papers. 2007. p. 79-86.

[31] Jordaan AJ. Entrepreneurial Self-Efficacy , Intrinsic Motivation , and Entrepreneurial Intention as Antecedents of Nascent NecessityEntrepreneur Business Start-Up Behaviour in South Africa : A Longitudinal Study: University of Adelaide; 2014.

[32] Fatoki OO. Graduate Entrepreneurial Intention in South Africa : motivations and obstacles. International Journal of Business and Management. 2010;5(9):87-98. 